\title{
REFLEXIVITY PRACTICES AS A TYPE OF A LAW EDUCATIONAL PROGRAM FOR THE DEVELOPMENT OF THE SKILLS OF AN IMPARTIAL OBSERVER IN JUDGES
}

\author{
Ivanskiy Valeriy Prokopievich \\ Ph.D. in Administrative and Finance Law Department of Law Institute, RUDN University, Russia, \\ ivansky_vp@pfur.ru
}

\begin{abstract}
The purpose of the article is to study the category of "impartiality" of a judge in the administration of justice and prepare recommendations for improving the skills of an impartial observer in the educational program's framework for judges' professional training. To achieve this goal, the following tasks were completed: first, the concept of impartiality of a judge was considered based on an analysis of international documents and a review of the European Court of Human Rights (ECHR). Second, the term "impartiality" is analyzed through the prism of basic concepts of emotions. Third, the practice of working with emotions (the practice of reflexivity), proposed by the philosopher M. Foucault, has been studied. Fourth, proposals are given to include reflexivity practices in professional development and professional training programs for judges in university courses. Based on the preceding, the novelty of the study lies in the fact that the author of the article not only analyzed the formal features of the term "impartiality" based on the jurisprudence of the ECHR, the nature of impartiality through the prism of modern approaches to emotions in law and classified them, but also concluded that impartiality is a state of consciousness that can be constituted through the practice of reflexivity.

For this reason, to acquire such skills and abilities by a judge, it is necessary to include educational programs of this type as a compulsory component of professional training and advanced training. The author made the following conclusions, paying attention to their practical significance: 1) the analysis of the judicial practice of the ECHR made it possible to formulate the concept of impartiality, which is understood as such a state of the legal psyche of a judge when no mental and emotional preferences or expressions of any interest in the verdict of the case in favor of one or another party to the proceedings; 2) a means of ensuring the impartiality of a judge is the practice of reflexivity (the practice of oneself), aimed at the formation of their inner qualities, which allow them to occupy the position of an impartial observer; 3 ) consolidation at the level of codes of judicial ethics of the need for the judicial community to organize law educational programs for advanced training and professional training of judges based on reflexivity practices.
\end{abstract}

Keywords: Education, Impartiality, Law, Practices of reflexivity, Judge, Professional training, Emotions.

\section{INTRODUCTION}

International acts and jurisprudence of the European Court of Human Rights (ECHR) thoroughly regulate the concept of an impartial and independent court as a requirement of a fair trial. Suppose the court's independence is ensured by legislative regulation of the judiciary's independence, which excludes any form of influence on adopting procedural decisions by the persons and bodies of the judicial and extrajudicial system. In that case, it is much more challenging to create formal guarantees for an impartial decision since 
this is related to the characteristics of the judge's personality. In this regard, it should be noted that impartiality, as a characteristic of the state of consciousness of a judge, in legal positivism is identified with the reason, where there is no place for the manifestation of any emotions when making a judicial decision. For this reason, under the almost century-long dominance of legal positivism, there was little or almost no scientific interest in the study of emotions, and therefore impartiality. It follows that if the concept of impartiality excludes emotions from its content, then the need for organizing the educational process associated with the acquisition of skills and abilities to work with emotions is lost.

However, the study of emotions in law has experienced a peak of new scientific interest in recent decades. There has been a clear tendency to rethink legal positivism in the modern philosophy of law, identified with impassive rationalism. In new scientific approaches to comprehending impartiality as a state of consciousness, emotions are not opposed to reason (rationality) but are recognized as an integral part of the cognitive process (see Huppes-cluysenaer L., Coelho N. M. M. S. (eds.). I. Borsch considers that the cognitive role of emotions is to contribute to judges' self-education through self-reflection. Nevertheless, there is still an unsettled problem with the mechanism for implementing educational programs for the development of the judge's skills and abilities of an impartial observer. Moreover, the practice of reflexivity (the practice of oneself) described by M. Foucault in his work "Hermeneutics of the Subject" can serve as a basis for developing programs for teaching judges the skills and abilities of an impartial observer. Consequently, the right to an impartial justice must be ensured by external guarantees - laws and internal practices of oneself, which can be developed and offered to the judicial community as an essentially practical course for judges' professional training.

Scientific works, devoted to the study of the legal nature of impartiality under the cut of concepts that reveal the essence of emotions, as well as the study of the practices (technologies) of mastering the states of consciousness by a judge, through which impartiality is provided to the greatest extent in the process of making a judicial decision, have not found the proper discussion in legal science. The above determines the relevance of the article.

\section{METHODOLOGY}

In the process of researching the legal category of "impartiality," the author used a diverse set of methodological tools - general scientific and unique methods. The study of objective impartiality is based on formal legal and comparative legal approaches, the dialectical method, and analysis and synthesis. The study of subjective impartiality, revealed through the description of the states of the legal psyche (or consciousness), relies on phenomenological (phenomenological-psychological and eidetic reductions) and psychological (introspection) procedures of cognition.

\section{RESULTS}

The analysis of international documents and the ECtHR jurisprudence, where the term "impartiality" is disclosed, showed that it is identified exclusively with the reason (rationality), which excludes emotional states of consciousness in its content. However, this review of scientific publications revealed various approaches to assessing emotions when making an impartial judge. The view that emotions harm a judge's impartial state of mind is called an irrational approach. There are other views, called cognitivism, according to which emotions contribute to the formation of such a state of consciousness when the maximum degree of impartiality of a judge is reached in the process of making a judicial decision. Such approaches dominate in foreign countries' scientific literature, where L. I. Petrazhitsky developed the ethical and legal approach. The foundation of his emotional theory of law is imperative-attributive experiences, the legal psyche's source. It is the latter that constitutes the state of impartiality. According to the author of the article, it is possible to develop an impartial observer's skills and abilities only based on the practices of reflexivity developed by M. Foucault. In this regard, it is proposed to include in educational programs for advanced training or professional training of judges, as a mandatory component, training, which includes obtaining theoretical knowledge, improving practical skills and abilities associated with forming an impartial state of consciousness.

\section{DISCUSSION (Impartiality and Emotion in Justice. Reflexivity practices)}

\subsection{The Concept of Impartiality of Justice in International Law and the Jurisprudence of the ECHR}

An impartial trial requirement is contained in international legal instruments as the International Covenant on Civil and Political Rights, American Convention on Human Rights, African Charter on Human and Peoples' 
Rights, European Convention for the Protection of Human Rights and Fundamental Freedoms, Magna Carta of Judges. Particular attention should be paid to paragraph 18 of the Magna Carta of Judges, which emphasizes that the ethical principles guiding the actions of judges should be included in professional training. Besides, the Recommendation of the Committee of Ministers of the Council of Europe, adopted on November 17, 2010, underlines the judicial ethics as a foundation for the independence and impartiality of judges (para 72), as well as on the fact that ethical principles should be fixed in codes of judicial ethics, developed by the judicial community (para 73).

The ECHR Rules (Art. 28) laid the foundation on which the doctrine of subjective and objective impartiality began to take shape. Over time, the ECHR practice was formed in cases concerning the description of the court's impartiality criteria. The European Court has developed two criteria for the category of "impartiality" subjective and objective. The court's subjective impartiality consists of a judge's interest, conviction, or bias in resolving a legal dispute. This principle can be manifested in the judge's statements related to the trial's verdict or the uttering of emotional judgments concerning the proceedings' participants. Objective impartiality means eliminating any doubts among the trial participants about the judge's bias, which can be determined by his external signs of behavior or how the trial is conducted.

\subsection{On Approaches to the Concept of impartiality of a Judge in Line with the Study of the Nature of Emotions}

Foreign scientists have considered emotions in law and their influence on the process of making an impartial court decision. A detailed analysis of the nature and classification of emotions in law was carried out by $P$. Mindus, which served as the basis for our selection of approaches to studying a judge's impartiality in modern legal doctrine. In Russian scientific publications, the influence of a judge's emotions on decisionmaking is analyzed mainly within the criminal process framework. An invaluable contribution to legal science was made by the famous legal scholar L.I. Petrazhitsky in the study of legal emotions (imperative-attributive experiences). During a review of the scientific literature, all points of view on the concept of impartiality through consideration of the relationship between reason and emotions in the administration of justice were brought to four approaches:

1) the formal-rationalistic approach expresses an impartial (objective) justice based on the concept of legal positivism, which is reflected only in the formal rationality, where emotions are an addiction that contributes to bias in making a judicial decision. Formal rationality is identified with such qualities of reason as isolation from emotions, which allows the judge not to be influenced by a particular situation when deciding a case. In this regard, A. Corbin argues that emotions negatively affect the light of the judge's pure reason in the administration of justice, plunging him/her into the twilight of ignorance. Justice is likened to the predictable mechanism of a machine. S. Bandes states that only emotionless justice can be impartial (objective) and fair;

2) the irrationalist approach admits the inevitability of the influence of chaotic, unbridled emotions (feelings, instincts) on adopting an impartial decision in the administration of justice. The judge's final decision is made up of formal rationality and irrational aspects - character traits, emotions (feelings), mood, beliefs, uncritically perceived thoughts, prejudices, and some others (see Ben-Ze'ev, Schauer). It follows from the above that jurists are aware of the inevitability of the influence of emotions on making a legal decision but differ in their views regarding their value. From the point of view of Supreme Court Justice J. G. Roberts, to better resolve a case, judges must let their emotions go;

3) the cognitive approach is based on understanding emotions (feelings) as a tool for mastering the information and a form of cognition. There is no opposition to emotions and reason, but their harmonious interaction is in an impartial decision-making argumentation. According to Reisenzein and Döring, emotions are not only involved in the analysis of the grounds for a legal decision, but we can also say that any judgments should be based on the content of emotions. I.R. Kaufman believes that intuition, emotion, and conscience are the proper factors for legal thinking. When a judge makes a decision, a unique role is given to the meaning of intuition (anticipation), based on the experience of emotional life, but not identified with an uncontrollable subconscious process (irrational emotions); (see Tersman F.)

4) the ethical and legal approach was developed by L. I. Petrazhitsky. He distinguishes between two types of ethical emotions - legal and moral experiences, the difference between which is that the former appears to our consciousness as external (incoming) impulses, and the second as internal (outgoing). External emotional-intellectual combinations form mental states called scientific law, and internal experiences are morality. Legal emotion arises only in those individuals who have a claim (authority) to demand the fulfillment of an obligation (duty) from others. In this regard, Petrazhitsky writes that a person's behavior is predetermined by his beliefs based on conscience, which is the source of genuine law, called intuitive law. 
Intuitive law is the highest criterion for distinguishing the just from the unjust act.

\subsection{Reflexivity Practices as a Type of Educational Program for Professional Development and Professional Training of Judges}

The formation of the personality of a lawyer, including a judge, is based, as a rule, on external psychological and pedagogical technologies: problem-based learning, multilevel learning, project-based learning, a research method, a lecture-tutorial credit system, the use of game methods in teaching, learning in cooperation, systems of innovative assessment "portfolio", and alike. Meanwhile, the above external educational technologies are provided by such a form of interaction as a teacher and a student, which are focused on developing standard psychophysiological features of students. However, they do not consider the specifics of such legal professions as the administration of justice by a judge, where its essential quality is impartiality. The purpose of external educational technologies is the assimilation of knowledge, the acquisition of skills and abilities that do not yet imply the formation of such personality features as conscientiousness, honesty, or impartiality. The latter quality, as already mentioned above, is the fundamental element of a fair court decision. M. Vilova, however, considers that in addition to external means of ensuring impartiality, the formation of the inner qualities of a judge, allowing him/her to occupy the position of an impartial observer, remains a cornerstone issue. As V. D. Spasovich assumes, justice is a matter more of conscience than of mind. Conscientiousness refers not to the intellectual, volitional, or moral spheres of the individual but the emotional. In this regard, one should agree with Chief Justice William J. Brennan's assertion that the greatest threat to the principle of due process is a legal reason, devoid of understanding of feelings. Therefore, a vital trait of a judge is his/her ability to maintain empathy (compassion) in court proceedings. However, external educational technologies cannot provide skills and abilities to manage emotions, especially in the professional activity of a judge.

One of the crucial professional qualities of a judge is the ability to control one's emotions (feelings), which can be developed with the help of reflexivity practices (practices of oneself) within the framework of educational programs, the foundation of which is the inner work of a person with himself. Such a program aims to form such a judge's quality as impartiality, where assistance is provided not by a teacher but by a mentor. From Foucault's point of view, a particular form of thought, which is created by the concept of "selfcare", allows one to become impartial. The concept of "self-care" includes training a judge with the abilities and knowledge (skills) that he must have acquired by the time he is appointed a judge. In M. Foucault's lecture course "Hermeneutics of the Subject" (1982), the concept of "practice of oneself" is given, which means the techniques with the help of which the subject makes the changes in himself necessary to gain access to the truth. (p. 27-28)

The French philosopher considers exercises in meditation, the study of consciousness, and control over ideas that appear in consciousness (p. 285) to be practices that change and transform themselves, standard for ancient philosophical schools. In other words, the task of practicing oneself (taking care of oneself) is not the transformation of "oneself" as a subject, a radical transformation of one's legal consciousness, but a change in the personal strategy of the judge's attitude to "oneself", through which the model of one's legal behavior, reactions, and life guidelines, which makes it possible to form an integral legal personality in it. Consequently, self-care practices (self/reflexivity practices) aim to improve the legal psyche by changing thinking, emotions, and actions.

The French philosopher distinguishes two types of exercises: 1) practice of oneself, the task of which is to mentally adjust to prepare for the transformation of oneself (meletan); and 2) techniques of oneself, with the help of which the subject makes sure that there is no external influence, because of which he/she understands that his/her transformation is not the result of external techniques of domination, but his/her direct spiritual labor (gimnazein). Foucault divides the latter practices into abstinence and self-examination (checking thoughts, impulses) (pp. 460, 546. -677). The above exercises can directly affect the legal psyche of a judge, his/her legal consciousness. Exercises of turning to oneself are characterized by control of destructive thoughts and harmful desires, neutralization of negative emotions, continuous comprehension of the life in law, which contributes to ensuring correct actions and deeds (see Lantern of Diogene, p. 116). Ensuring correct actions and deeds, according to M. Foucault, can be achieved through exercises "for the assimilation and mastery of thought." (Hermeneutics of the subject pp. 384-388). In this context, the "welldeveloped" legal thinking of a judge can become a practical regulation that influences the fair judicial decision. Therefore, as Shvets states, practicing oneself changes a person's lifestyle and helps to achieve a state of dispassion and inner harmony. (pp. 227-233.) 


\section{CONCLUSION}

1. Based on the analysis of the legal practice of the ECHR, the concept of impartiality was formulated, which is understood as such a state of the legal psyche of a judge when, before making a final decision, no mental and emotional preference or expression of any interest in the decision of the case in favor of one or another party is given.

2. The category of "impartiality" is revealed through the prism of approaches to the concept of the nature of emotions in law, which can be considered within the framework of the following scientific approaches: 1) an impartial decision in justice is based solely on reason without any influence of emotions on its implementation. Therefore, emotions are unacceptable in justice; 2) the impartial decision-making process is negatively affected by emotions, which cannot be distanced; 3) impartial decision-making is the result of harmonious interaction of emotions (feelings) and reason; 4) an impartial decision is an experience of justice based on the requirements of intuitive legal norms (intuitive law).

3. The practice of reflexivity (the practice of oneself / taking care of oneself) is a means of ensuring the impartiality of a judge, aimed at the formation of his/her inner qualities, which allow him/her to occupy the position of an impartial observer. In this regard, we assume it necessary to introduce reflexivity practices into educational programs for professional training and professional development of judges to develop the mental skills of an impartial observer.

4. Ethical principles of judicial behavior developed by the judicial community are fixed in judicial ethics codes. Para 18 of Magna Carta of Judges states that ethical principles should be included in professional training. Meanwhile, M. Foucault's reflexivity practices are the ethics of oneself. Practices of themselves are a combination of ethical theory and moral practice (ethical prescriptions for self-care).

5. In this regard, it is necessary to consolidate at the level of codes of judicial ethics the need for the judicial community to organize educational programs for advanced training and professional retraining of judges based on the practices of reflexivity (the practice of self) developed by M. Foucault. Thus, clause 18 of Magna Carta of judges should be supplemented with a provision on the mandatory inclusion of practitioners in the professional training of judges in educational programs to acquire theoretical knowledge, improve practical skills and abilities related to achieving an impartial state of consciousness.

6. Three forms of spiritual exercises in thinking (forms of reflexivity) are distinguished: 1) reflexivity in the form of memory, consisting of remembering and recognizing a forgotten source, as a result of which the subject renews and changes; 2) reflection in the form of thinking as meditation presupposed checking (inspection) of the soul in order to build up the correct spiritual alignment; 3) reflexivity in the form of thought as a method necessary for developing criteria for verifying the truth.

\section{ACKNOWLEDGEMENT}

This paper has been supported by the RUDN University Strategic Academic Leadership Program.

\section{REFERENCE LIST}

Huppes-cluysenaer L., Coelho N. M. M. S. (eds.). (2018) Aristotle on Emotions in Law and Politics. Berlin: Springer. $473 p$.

Borshch, I. (2018) Emotions in law and politics: from Aristotle to our days' jurisprudence. Sociological Review. Vol. 17. No. 2. pp. 356-362

Foucault, M. (2007) Hermeneutics of the subject: a course of lectures given at the College de France in the 1981-1982 academic year. Translated by A.G. Pogonyaylo. Saint Peterburg: Nauka.

International Covenant on Civil and Political Rights (Adopted by Resolution 2200 A (XXI) of the UN General Assembly of December 16, 1966), URL: http://www.un.org/ru/documents/decl_conv /conventions/pactpol.shtml (accessed 06.12.2020)

American Convention on Human Rights (adopted by the Inter-American Conference on Human Rights in San Jose on November 22, 1969. Entered into force on July 18, 1978), URL:

http://www1.umn.edu/humanrts/russian/instree/Rzoas3con.html (accessed 06.12.2020) 
African Charter on Human and Peoples' Rights (Adopted at the meeting of the Heads of State of the Organization of African Unity on June 26, 1981 in Nairobi) URL:

http://www.ohchr.org/Documents/Publications/training9chapter3ru.pdf (accessed 06.12.2020)

Convention for the Protection of Human Rights and Fundamental Freedoms of November 4, 1950 // SZ RF. 2001. No. 2. Art. 163)

Magna Carta of Judges (Fundamental Principles). Adopted by CCEJ at 11th plenary meeting. Strasburg, 1719 November 2010. URL: https://rm.coe.int/16807482c6 (accessed: 20.09.2020).

Recommendation of the Committee of Ministers of the Council of Europe CM/Rec (2010) 12 "On the independence, efficiency, and responsibility of judges" of November 17, 2010. Translated by B.L. Zimnenko Russian justice. 2011. No. 4

Regulation of the European Court of Human Rights as of December 1, 2005. Bulletin of the European Court of Human Rights. Russian edition. 2006. No. 4. p. 88

ECtHR Judgment in Padovani v. Italy, 26 February 1993 (application no. 13396/87), para 20. URL: http://cmiskp.echr.coe.int/tkp197/search.asp?skin=hudoc-en (accessed 11.01.2020), ECtHR judgment in the case Morel v. France of June 6, 2000 (application no. 34130/96), para 41. URL: http: //cmiskp.echr.coe.int/tkp197/search.asp?skin=hudoc-en (accessed 01.11.2020).

ECtHR judgment in the case Buscemi v. Italy, dated September 16, 1999 (application no. 29569/95) //http://cmiskp.echr.coe.int/tkp197/view.asp?item=1\&portal=hbkm\&action=html\&highlight=Buscemi\%2 0\% 7C\% 20v.\% 20\%7C\%20ltaly\&sessionid=48658344\&skin=hudoc-en (accessed 01.11.2020)

Mindus, P. (2016) The wrath of reason and the grace of feelings: substantiating emotions in law. News of higher educational institutions. Jurisprudence. No. 2 (325). pp. 6-47

Manoilova, S.A. (2005) Emotions in criminal law: dissertation on Ph.D. Yaroslavl, 214p.;

Chernova, N.A. (2018) Emotions associated with a crime: concept, types, problems of accounting for criminal cases: monograph. Moscow: Yurlitinform Publishing House, 52 p.

Corbin, A.L. (1914) The Law and the Judges. Yale Review. No 3. pp. 234-250.

Bandes, S. A. (2011) Moral Imagination and Judging. Washburn Law Journal. No 51. p. 104;

Henderson, L. (1987) Legality and Empathy. Michigan Law Review. No 85. pp. 1574-1653; Posner, R.A. (2008) How Judges Think. Harvard University Press, pp. 229.

Ben-Ze'ev, A. (2018) Preface to the Philosophy of Emotions. Philosophia 46 (3). pp. 501-503;

Schauer, F. (2009) Thinking Like A Lawyer. Cambridge (Mass.): Harvard University Press.

Fiss, O.M. (1990-91) Reason in All Its Splendor. Brooklyn Law Review. 1990-1991. No 56. p. 797.

Reisenzein, R., Döring, S. (2009) Ten Perspectives on Emotional Experience: Introduction to the Special Issue. Emotion Review. No 1., pp. 195-205.

Kaufman, I. R. (1984) The Anatomy of Decision-making. Fordham Law Review. 53: 1. p. 16.

Tersman, F. (2012) Intuitional Disagreement. The Southern Journal of Philosophy. No 50. pp. 639-659.

Hutcheson, Jr. J.C. (1929) The Judgment Intuitive: The Function of the «Hunch» in Judicial Decision. Cornell Law Review. No 14. pp. 274-288.

Petrazhitsky, L.I. (1900) Essays on the philosophy of law. Saint Peterburg, pp. 10-11.

Vilova, M. G. (2015) The concept of "impartial observer" as the basis of the court's impartiality. Magistrate judge. No. 7. pp. 7.

Spasovich, V.D. (2000) On the theory of criminal forensic evidence in connection with the judicial system and legal proceedings. Spasovich V.D. Selected works and speeches. Compiled by I.V. Potapchuk. Tula: Autograph, p. 85.

Brennan, Jr. W.J. (1988) Reason, Passion, and the Progress of the Law. Cardozo Law Review. No 10:3. p. 17.

Lantern of Diogenes. Synergistic anthropology project in a modern humanitarian context. Ed. by S.S. 
Horuzhy. Moscow: Progress-Tradition, 2010. p. 116).

Shvets, I.V. (2015) On the purpose and internal characteristics of spiritual practices in the works of M. Foucault. Bulletin of the Irkutsk State University. Series: Political Science. Religious studies. Vol. 12. pp. 227-233. 